Multidisciplinary

SCIENTIFIC JOURNAL OF

MARITIME RESEARCH

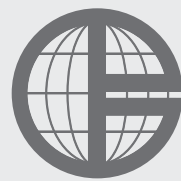

University of Rijeka

Faculty of Maritime

Studies Rijeka
Multidisciplinarni

znanstveni časopis

POMORSTVO

\title{
Beaches as a Factor in Achieving Competitiveness of a Tourist Product-Case Study: Istrian County
}

\author{
Zrinka Zadel, Daniela Gračan, Vedran Milojica \\ University of Rijeka, Faculty of Tourism and Hospitality Management Opatija, Primorska 42, 51410 Opatija, Croatia, e-mail: zrinkas@fthm.hr; \\ danielag@fthm.hr; vedran.milojica@gmail.com
}

\section{ABSTRACT}

Beaches are the main part of an integral tourist product of a destination. They represent a highly valuable resource from the aspect of natural, social, economic and recreational potential. They make a tourist product attractive, and represent a motive of arrival to a destination for a certain number of tourists. In order for a beach to be placed in a function of tourist offer and positioning of a tourist destination on the tourist market, and for destination's tourist product to become more attractive, it is necessary to enrich the offer of beaches according to the desires of market segment while respecting the principles of sustainable development. Beach offer of the Istrian County has been analysed within this paper. While preparing this paper, the authors have used the scientific methodology, which means gathering and the analysis of data from primary and secondary sources. An analysis of domestic and foreign professional and scientific literature has been carried out, as well as the valid law frame of beach managing in the Republic of Croatia. With a goal of analysing the existing state of regulation and managing beaches in the Istrian County, an evaluation of beach resources has been carried out.
\end{abstract}

\section{ARTICLE INFO}

Review article

Received 5 May 2018

Accepted 6 June 2018

Key words:

Beaches

Tourist product

Competitiveness model

Tourist destination

Istrian County

\section{Introduction}

Tourism market represents a very dynamic market, and is marked by fast changes from both tourists offer and demand. Contemporary trends register not only a faster growth of tourist preferences, but also that they are becoming increasingly specific. In order to achieve success on the tourist market, as well as competitive positioning, it is necessary to ensure timely adjustment of tourist offer to the tourist demand. Only those destinations, which form destination product based on the desires and needs of tourists, will achieve success (Zadel and Cerović, 2013). Within a Croatian tourist product, classical Sun, sea, sand (3S) offer has remained dominant throughout the years, and the current situation is not different. One of the counties, whose efforts and activities are emphasized in terms of development of this tourism form is the Istrian county. Many investments were made into the development of its beaches and its facilities. Within this paper, the authors will present, through adequate theoretical background, the importance and characteristics of beaches in the
Istrian county, as well as the results of an empirical research in which attitudes of tourists towards beaches and bathing tourism offer will be presented. Finally, concluding remarks will be provided.

\section{Theoretical Background}

Competitiveness among tourist destinations has been growing due to numerous international tourism activities, which occur on daily basis. That brings the importance of the assessment of destination performance vis-a-vis other similar and competing destinations (Kozak, 2002). Competitiveness and how to achieve it on the turbulent tourist market has been a subject of numerous scientific and professional studies for many years, and from various points of view. In order to make a clearer insight, the authors will present briefly some of them. Duman and Kozak (2010), i.e., carried out an analysis of tourism resources in Turkish cities by using the content analysis of official tourism websites of Turkish cities. They also surveyed the tourism officials in Turkish cities in order to identify 
their descriptions of the cities in which promotion they are actively involved. Based on the findings they were able to determine and propose developmental directions, respectively where to focus in order to improve the level of the achieved level of competitiveness of a Turkish tourist product. Goffi (2013) undertook further efforts into developing Ritchie \& Crouche's model (2000) to a higher level by adding further determinants to their original competitiveness model, and testing the model on the Italian destinations of excellence. The model contains: 1 . core resources and key attractors (natural resources, green areas, leisure activities, gastronomy and typical services, etc.); 2. tourist services (quantity and quality of accommodation, food services quality, tourist oriented services, etc.); 3.general infrastructures (environmental friendliness and quality of transportation services, quality of road system, medical care facilities, sanitation, sewage and solid waste disposal, etc.); 4. conditioning and supporting factors (accessibility of destination, proximity of other destinations, destination links with major origin markets, value for money in destination tourism experience, etc.); 5 . tourism policy, planning and development (political commitment to tourism, integrated approach to tourism planning, clear policies in creating formal employment opportunities, etc.); 6. destination management (effectiveness of destination positioning, effective market segmentation, tourist destination communication, effectiveness in crafting tourism experiences, etc.); and 7. demand factor (awareness of destination, level of repeat visitors, "Fit" between destination products and visitor preferences, etc.). The results of the empirical research and testing confirmed the validity of the model and its success in determining the level of competitiveness of a tourist destination and its offer. According to Dwyer and Kim (2003), in order to achieve competitive advantages for its tourism industry, any destination must enable that adequate "appeal" as well as the experience offered to the tourists, which must be superior among all the alternative destinations available. An existing and potential visit to a destination is inextricably linked to that destination's overall competitiveness.

Every destination bases its tourist offer development on comparative advantages (this refers to both natural and created destination attributes) which makes it unique and recognizable on the tourist market, and stimulates potential tourist to visit a certain destination. These attributes need to be maintained and managed carefully while upholding sustainability principles, in order to enable their preservation in the long-run (Garcia Sanchez et al, 2015; Porter, 1990), and achieve competitive advantages on the tourist market.

World tourism flows experience numerous changes on daily basis. However, one thing that remained the same over the years is that Sun, Sea, Sand (3S) offer still holding the leading position, due to the fact that numerous destinations primarily base their offer on its natural and other particularities, and beaches represent a primary resource.

Beaches can be defined as a cluster of unconsolidated material (e.g. sand, gravel, clay or mixtures thereof), extending from the land edge of the beach, which can be slopes of dunes or seawall, to the depths of the sea, where there is no significant movement of sediment (Gračan et al., 2016, p. 76; Williams and Micaleff, 2009, p. 10).

Beaches can be defined in relation to a wide spectre of physical and anthropogenic determinants, which, among other things, include sea physics (primary relates to the influence of waves), material contents, colour of beach sediment (often used in order to describe various types of beaches) and others.

In relation to the anthropogenic dimension, the beach type can be determined according to the three main criteria:

- degree of naturalness (natural or artificial beach);

- degree of use (beaches used intensively, moderately and little);

- beach environment and types of facilities that are being offered (remote, rural, local, urban or resort beach within a tourist complex).

While taking into consideration recreational characteristics of beaches, the Physical Planning and Building Act (NN 76/07, 38/09, 55/11, 90/11, 50/12, 55/12), in article 53 divides beaches into arranged and natural sea beaches. Furthermore, it is determined that:

- arranged sea beach within or outside the settlement is supervised and accessible to everybody under the same condition from the mainland and seaside, including people of reduced mobility, mostly edited and altered natural characteristics, and arranged mainland space from the point of infrastructure and facilities (showers, cabins and sanitation), immediately connected with sea, marked and protected from the seaside;

- natural sea beach within or outside the settlement supervised and accessible from the mainland and/or sea side, unequipped from the point of infrastructure, totally preserved found natural characteristics.

Rethinking beaches in the context of their use, the Regulation on the Procedure for Granting a Concession on a Maritime Domain (NN 23/04, 101/04, 39/06, 63/08, $125 / 10$ and 83/12 - furthermore defines beaches as:

- arranged public beaches - beaches in use to the major number of tourist facilities and citizens;

- arranged special beaches - beaches that make a technical and technological unit of an accommodation unit in the sense of Law on Restaurant Business;

- natural beaches - beaches on which there was no interventions within their space in the sense of the Regulations that are regulating Spatial Planning and Building, and which must not be limited from the mainland.

According to the Bathing Area Registration and Evaluation System (BARE) within the National Programme of Managing and Setting Beaches (2014), they can be divided into the following ones:

- Remote beach: usually determined by poor access (mostly by sea path or walking at least 300 metres), they can be in the vicinity or on the edge of rural, or sometimes village (local) areas, but not urban. They cannot be reached by public transport. In the Mediterranean context, in such 
areas it is possible to find a limited number of holiday houses as well as a small number of restaurant businesses open in the summer period;

- Rural beach: situated mostly outside urban/local areas, but can also be situated within the settlements. They are unreachable by public transport, but there are access routes, and they can be reached by public transport. These beaches do not have restaurant facilities. However, in the Mediterranean context, some overland recreational facilities or seasonal beach facilities (i.e. pedalling, "bananas" or water skiing) can be found in rural beaches. In these beaches, the hinterland is not built in a significant measure, however, some accommodation units can be found, but there are no, or there is a small number of permanent social facilities (elementary school, church, store, restaurant business, etc.). They are appreciated by the tourists due to peace and preserved natural qualities;

- Local beach: situated outside major urban surroundings and connected with minor, but constant population that has an access to the organized service activities in a smaller range, such as elementary school, church, stores and restaurant businesses. These beaches also can be found in tourist resorts or camps, which are used mostly in summer months, as well as within inhabited areas between urban and rural areas with developed offer of family accommodation. In relation to the rural beaches, the basic difference is their setting. While rural beaches are mostly natural, public beaches are reachable by public transport or by cars;

- City (urban) beach: situated in the urban area which serves a large population with well-organized service facilities such as elementary schools, churches, banks, post offices, centres of primary healthcare protection, restaurant businesses and other urban facilities. Nautical tourism ports can be found in the vicinity of city beaches;

- Resort beach (which makes a technical-technological unit of some accommodation) has three expressive characteristics: a) it is in the vicinity of accommodation facilities and the majority of its users are the guests of these lodging facilities; b) beach running is the responsibility of the previously mentioned tourist resort, which includes cleaning beaches, ensuring a wide variety of recreational facilities and activities - loungers, pedals, jet-skis, "parasailing", surfing, various activities which include speedboat pulling (the ring, "banana", water-skiing), sailing and diving and coffee shops/restaurants for the beach users. An excellent example for this type of beaches is the organization of the Club Med, an accommodation complex in private ownership, which consists of hotels/bungalows with plenty of restaurant, recreational and entertainment facilities. In some cases, such as "all-inclusive" arrangements, the majority of these services are free for all guests. A large majority of the beach users in a tourist resort uses these facilities for recreational purposes, and not just for relaxation (sunbathing).

As a tourist resource, on which bathing tourism offer is based, beaches significantly enrich the tourism offer of the destinations located along coastal areas as well as on river and lake banks. They represent the natural, social and economic (recreational) source. Beaches in tourism represent a highly valuable resource due to the fact that beaches represent one of the main motives for undertaking a journey. The quality of the bathing tourism product depends on how beaches are evaluated. Bathing tourism is characterized by a mass of tourists, so it is necessary to bear in mind that tourism evaluation must reflect the tourist preferences, and, at the same time, the offer must be developed in such a way as to uphold sustainability principles. Only through this, it is possible to achieve tourist satisfaction with the economic effects at the same time (Zadel, 2015).

This is also acknowledged by Semeoshenkova \& Williams (2011 according to Bojanic, 1992; Vaz et all, 2009), who also emphasized in their work that within tourism industry, as the fastest growing economic sector on world level, beaches are being considered as the main and most important factor which influences that growth. For the majority of tourists, the presence and good quality of a beach and its facilities represents the most important and the most attractive factor in the process of decisionmaking when choosing a holiday destination. Beaches and near shore-based waters provide for tourists a possibility for sunbathing, relaxing, and other activities such as swimming, surfing, yachting, fishing, jet skiing. Beaches represent the most important recreational and leisure areas which significantly influence the development of coastal countries' economy.

In order for a tourist destination to achieve a higher level of development of its tourist offer, and to achieve competitiveness on the tourist market, it is important to determine its state, as well as the attitudes that tourists have, in order to rethink which are the best possible ones and how to improve them in the best possible way. In the world, beaches are a significant source of income, and in the last few years, the interest is growing due to the possibility of using their recreational and economic potential. The Republic of Croatia has made significant breaks through the years in terms of this form of tourist offer development.

Besides numerous regulations and projects of the European and world councils and organizations dealing with ecology and sustainable development, and on the national level as well, documents and action plans of beach running have been brought with a goal of increasing beach quality and competitiveness, which necessarily brings to the increase of their economic evaluation. In 2018 the Ministry of Environment and Energy has brought the Strategy of Managing Sea Environment and Coastal Area aimed at protecting the marine environment. The significance of beaches for the further development of tourism in the Republic of Croatia was recognized by the Ministry of Tourism, which, in 2014, brought the National Programme of Managing and Arranging Sea Beaches with a unique database of all beaches and their facilities out of which the process of their theming arose. Regional plans of beach theming were made further on the county level. One of them is the Istrian County, which is the subject of research in this paper. 
Many activities have been focused towards development of various specific forms of tourism, but bathing tourism still remained the leading within the tourist product. One of the Croatian counties which need to be pointed out in particular is the Istrian County. In the following chapter the authors will present a brief theoretical review of the state of the tourist offer of the Istrian County with a particular emphasis on its beach resources, as well as tourists' attitudes towards beaches within the Istrian County. Based on this, they will offer a direction of the future development of bathing tourism in Istria.

\section{Characteristics of Beaches as a Part of the Istrian County's Tourist Offer}

According to the 2015 - 2025 Master Plan of Tourism of the Istrian County (2014), Istria is the most western county in the Republic of Croatia, and territorially organized into 41 units of local self-government, respectively 10 cities and towns and 31 larger rural municipalities with Pazin as the seat of the county. Its area covers 3,476 square kilometres, of which the majority, 3,130 square kilometres (90\%) belongs to the Republic of Croatia, while the rest belongs to the neighbouring Slovenia and Italy. The majority of the Croatian part of the Peninsula is situated in the Istrian County $\left(2,820 \mathrm{~km}^{2}\right)$. Its climate is conditioned by the fact that Istria, as a peninsula, is surrounded by the sea from three sides, so the climate varies from the Mediterranean to the Continental one. Summers are dry and warm. The temperature is influenced by the mainland, sea, and the elevation. In the summer period, it can reach up to $40^{\circ} \mathrm{C}$. The temperature of the sea is the lowest in March $\left(9^{\circ}-11^{\circ} \mathrm{C}\right)$, and the highest in August (up to $24^{\circ} \mathrm{C}$ ). The sea salinity is $36-38 \%$. In terms of traffic connection, it is well connected by sea, air and road. Over the years, many activities have been invested in the development of a competitive tourist product on the county level (with particular emphasis on specific forms of tourism, such as bathing tourism, rural tourism, nautical tourism, etc., the offer being based on Istria's comparative advantages), which is witnessed by the growing tourist turnover presented in the following table.

The data in the Table 1 have indicated a positive growth of both tourist arrivals and overnights, with foreign tourists as a significant majority, thus indicating that Istria has been indeed recognized as a tourist destination on the international tourist market. Bathing tourism has justifiably remained a dominant tourist product in this county due to high investments in beach running and development.

Table 1 Tourist Arrivals and Overnights in the Istrian County in the 2014-2017 Period

\begin{tabular}{|c|c|c|c|c|c|c|}
\cline { 2 - 7 } \multicolumn{1}{c|}{} & \multicolumn{3}{c|}{ Arrivals } & \multicolumn{3}{c|}{ Overnights } \\
\cline { 2 - 7 } \multicolumn{1}{c|}{} & Total & Domestic & Foreign & Total & Domestic & Foreign \\
\hline 2014 & $3,059,226$ & 174,289 & $2,884,937$ & $19,545,303$ & 616,781 & $18,928,522$ \\
\hline 2015 & $3,369,905$ & 189,711 & $3,180,194$ & $20,966,561$ & 661,409 & $20,305,152$ \\
\hline 2016 & $3,763,174$ & 222,421 & $3,540,753$ & 23.128 .233 & 741.019 & $22,387,214$ \\
\hline 2017 & $4,104,018$ & 228,926 & $3,875,092$ & 25.426 .476 & 723.578 & $24,702,898$ \\
\hline $2017 / 2014$ & $34.15 \%$ & $31.35 \%$ & $34.32 \%$ & $30.09 \%$ & $17.32 \%$ & $30.51 \%$ \\
\hline
\end{tabular}

Source: Statistical Bureau of the Republic of Croatia www.dzs.hr

Table 2 Characteristics of Beaches in the Istrian County with the Blue Flag Awarded in 2017

\begin{tabular}{|c|c|c|c|c|}
\hline Name & City & Type & Sort of beach & Contents \\
\hline Beach Katoro & Umag & $\begin{array}{l}\text { Natural/ } \\
\text { arranged }\end{array}$ & $\begin{array}{l}\text { Pavement, } \\
\text { gravel, sand }\end{array}$ & $\begin{array}{l}\text { Showers, changing cabins, aqua gun, bars, restaurants, tennis and } \\
\text { volleyball playground, children's playground }\end{array}$ \\
\hline Beach Kanova & Umag & $\begin{array}{l}\text { Natural/ } \\
\text { arranged }\end{array}$ & Rocks, pavement & $\begin{array}{l}\text { Public parking, sunbathing lawn, benches, natural shady places, ice } \\
\text { cream, fast food, beach bar, coffeehouse, restaurant, supermarket, } \\
\text { kiosk, shop with beach accessories, beach chair rentals, beach } \\
\text { umbrella rental, showers, changing rooms, public toilets, lifeguards, } \\
\text { inflatable floating island, children's playground, beach volleyball, } \\
\text { rent a boat, rent a bicycle, parasailing, diving, table tennis, tennis }\end{array}$ \\
\hline $\begin{array}{c}\text { Beach Laguna } \\
\text { Stella Maris }\end{array}$ & Umag & Natural & $\begin{array}{c}\text { Concrete } \\
\text { plateaus, fine } \\
\text { gravel, gravel }\end{array}$ & $\begin{array}{l}\text { Public parking, sunbathing lawn, benches, natural shady places, } \\
\text { ice cream, fast food, beach bar, coffeehouse, restaurant, kiosk, } \\
\text { beach chair rentals, beach umbrella rental, showers, changing } \\
\text { rooms, public toilets, barrier-free access to the sea, first aid, life- } \\
\text { guards, seawater slide, inflatable floating island, beach volleyball, } \\
\text { rent a bicycle }\end{array}$ \\
\hline
\end{tabular}




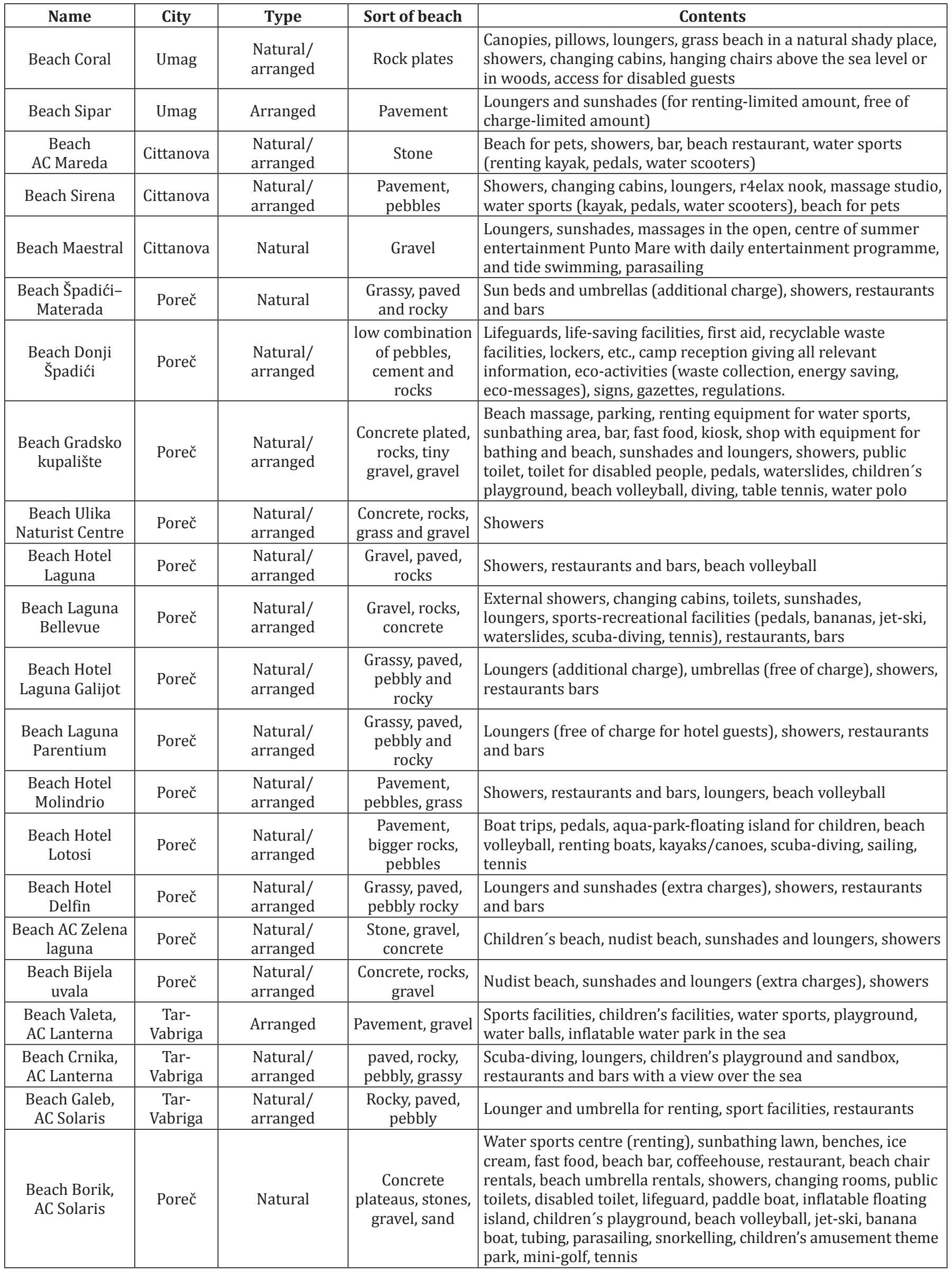




\begin{tabular}{|c|c|c|c|c|}
\hline Name & City & Type & Sort of beach & Contents \\
\hline Beach Riviera & Poreč & Natural & Pebbles & Loungers with canopies, orbit lounge chairs, beach bar \\
\hline Beach Brulo & Poreč & Natural & Pebble & $\begin{array}{l}\text { Aqua gun, parasailing, iceberg, pedals, bananas, amusement } \\
\text { theme park, trampoline, playground, scuba-diving, sunshades } \\
\text { and loungers, external showers, changing cabins, toilet, bars and } \\
\text { restaurants }\end{array}$ \\
\hline Beach AC Istra & $\begin{array}{l}\text { Funtana- } \\
\text { Fontne }\end{array}$ & Natural & $\begin{array}{l}\text { Pebbly and rocky } \\
\text { naturist with } \\
\text { rocky sunbathing } \\
\text { areas }\end{array}$ & Beach for children, beach for dogs, canoeing, showers \\
\hline Beach Vala & Vrsar & Natural & $\begin{array}{l}\text { Rocky } \\
\text { sunbathing } \\
\text { areas, some } \\
\text { pebbles }\end{array}$ & $\begin{array}{l}\text { Sun loungers and umbrellas (extra charge), showers, changing } \\
\text { cubicles lifeguards, sports centre offering water sports, diving } \\
\text { centre and boat rental, massage (extra charge), sandbox for } \\
\text { children, showers for pets (the dog beach) }\end{array}$ \\
\hline $\begin{array}{l}\text { Beach AC } \\
\text { Valkanela }\end{array}$ & Vrsar & $\begin{array}{l}\text { Natural/ } \\
\text { arranged }\end{array}$ & $\begin{array}{l}\text { Stone, pebbly, } \\
\text { rocky, concrete, } \\
\text { sandy, stone } \\
\text { plateaus }\end{array}$ & $\begin{array}{l}\text { Access at the central beach for disabled persons and people with } \\
\text { special needs, sun-loungers and parasols rentals, dog friendly } \\
\text { beaches, beach showers }\end{array}$ \\
\hline $\begin{array}{l}\text { Beach AC Porto } \\
\text { Sole }\end{array}$ & Vrsar & $\begin{array}{l}\text { Natural/ } \\
\text { arranged }\end{array}$ & $\begin{array}{l}\text { Gravelly, rocky, } \\
\text { stone plateaus, } \\
\text { paved, pebble }\end{array}$ & $\begin{array}{l}\text { Sunbathing, beach for dogs, showers on the beach, renting } \\
\text { loungers and sunshades }\end{array}$ \\
\hline $\begin{array}{l}\text { Beach Koversada } \\
\text { Naturist Centre }\end{array}$ & Vrsar & $\begin{array}{l}\text { Natural/ } \\
\text { arranged }\end{array}$ & $\begin{array}{l}\text { Rocky, pebble, } \\
\text { stone, concrete } \\
\text { plateaus }\end{array}$ & $\begin{array}{l}\text { Children's beach, sunshades and loungers for renting, showers } \\
\text { on the beach, beach for dogs }\end{array}$ \\
\hline $\begin{array}{l}\text { Beach Sv. } \\
\text { Andrija, Crveni } \\
\text { otok }\end{array}$ & Rovinj & Natural & $\begin{array}{l}\text { Rocky, gravel, } \\
\text { sand }\end{array}$ & Showers, Sun-loungers and parasols \\
\hline $\begin{array}{l}\text { Beach } \\
\text { "Entertainment } \\
\text { center" TN Villas } \\
\text { Rubin }\end{array}$ & Rovinj & $\begin{array}{l}\text { Natural/ } \\
\text { arranged }\end{array}$ & $\begin{array}{l}\text { Pebble, rocky, } \\
\text { paved, sandy, } \\
\text { stone plateaus, } \\
\text { concrete } \\
\text { plateaus } \\
\end{array}$ & $\begin{array}{l}\text { Loungers for renting, small boat quay, launch ramp, shower on } \\
\text { the beach }\end{array}$ \\
\hline Beach AC Veštar & Vrsar & Natural & Pebbles, rocks & Loungers and sunshades for renting, showers on the beach \\
\hline Beach Barbariga & Vodnjan & Natural & rocky, pebble & $\begin{array}{l}\text { Restaurant and a bar, sunbeds and parasols, lifeguard service, } \\
\text { beach volleyball }\end{array}$ \\
\hline Beach Peroj & Vodnjan & Natural & Large pebble & No data \\
\hline Beach Bi-val & Fažana & Natural & $\begin{array}{l}\text { Gravel, partially } \\
\text { sand }\end{array}$ & $\begin{array}{l}\text { Sports facilities, access for disabled tourists, external showers, } \\
\text { changing cabins, toilet, children's playground, riding a "banana", } \\
\text { tube, pedals, aqua gun, jet ski, water skiing, small school of } \\
\text { sailing and scuba-diving, bike and kayak }\end{array}$ \\
\hline Beach Ambrela & Pula & Natural & Rocks, pebble & $\begin{array}{l}\text { Outdoor showers, public toilets, changing cabins, restaurant, } \\
\text { café, sunshades, loungers, pedal boats and aqua-park. }\end{array}$ \\
\hline Beach Brioni & Pula & $\begin{array}{l}\text { Natural/ } \\
\text { arranged }\end{array}$ & $\begin{array}{l}\text { Rocks, partially } \\
\text { paved }\end{array}$ & Jet skiing, banana rides, parasailing, boat rental, underwater park \\
\hline Beach Histria & Pula & $\begin{array}{l}\text { Natural/ } \\
\text { arranged }\end{array}$ & Stone, concrete & $\begin{array}{l}\text { Restaurant and a bar, sunbeds and parasols for rent, lifeguard } \\
\text { service, beach volleyball court, tennis courts, squash courts, pool } \\
\text { and aqua-gun, animation }\end{array}$ \\
\hline Beach Maslinica & Rabac & $\begin{array}{l}\text { Natural/ } \\
\text { arranged }\end{array}$ & Stones, gravel & $\begin{array}{l}\text { Public parking, ice cream, fast food, beach bar, coffeehouse, } \\
\text { restaurant, supermarket, kiosk, shop with beach accessories, } \\
\text { beach chair and umbrella rental, showers, changing rooms, } \\
\text { public toilets, lifeguard, paddle boat, water slide, inflatable } \\
\text { floating island, rent a boat, trampoline, tennis, basketball, soccer }\end{array}$ \\
\hline Beach St. Andrea & Rabac & Natural & $\begin{array}{l}\text { Rocks, gravel, } \\
\text { tiny gravel }\end{array}$ & $\begin{array}{l}\text { Parking, fruit and vegetable shopping, ice-cream, fast food, } \\
\text { beach bar, coffee shop, pedals, aqua park-floating park for } \\
\text { children, children's playground, renting boats, scuba-diving, } \\
\text { entertainment park, mini-golf }\end{array}$ \\
\hline
\end{tabular}




\begin{tabular}{|c|c|c|c|l|}
\hline Name & City & Type & Sort of beach & \multicolumn{1}{|c|}{ Contents } \\
\hline Beach Lanterna & Rabac & Natural & Rocks, gravel & $\begin{array}{l}\text { sunbathing lawn, benches, fast food, beach bar, coffeehouse, } \\
\text { restaurant, kiosk, shop with beach accessories, beach chair } \\
\text { rentals, beach umbrella rental, showers, changing rooms, public } \\
\text { toilets, first aid, lifeguard, paddle boat, rent a boat, banana boat, } \\
\text { tubing, snorkelling }\end{array}$ \\
\hline Beach Girandella & Rabac & Natural & Gravel & $\begin{array}{l}\text { Loungers and sunshades, floating water park, water sports, } \\
\text { beach bar, towels, changing cabins, showers, lifeguard }\end{array}$ \\
\hline
\end{tabular}

Source: Author's interpretation according to Tourist Board of Funtana, Tourist Board of the city of Vodnjan, Official website of a tourist agency Istriasun, Pula Travel Guide PulaCroatia, Official website of Travelana d.o.o. Travel Agency, Official website of Uniline Travel Company, Official Website of Laguna Poreč Hotels Resorts \& Camping, Official website of Adriagate Travel Agency, Official Website of Aminess Hotels \& Camps, Official Website of Arenaturist Hotels \& Resorts, Official Website Best of Croatia company, Official Website of Camping by Valamar, Official Website of Maistra Camping Rovinj Vrsar, Official Website of tourist agency Gradtur d.o.o. and hrvaska.net, Official website of Istraturist Hotel Resorts \& Campsites, Official Website of Maistra Hotels \& Resorts, Official Website of the Tourist Board of Poreč, Official Website of Valamar Hotels \& Resorts (accessed 11 ${ }^{\text {th }}$ March 2018)

The Table 2 presents all the beaches in the Istrian County that have been awarded with the Blue Flag $^{1}$, international ecology programme of marine and coast environment protection, primarily aimed at a sustainable managing of the sea and the coastal line (which ensures a clean sea and a well maintained and organized environment), divided according to the city where they are situated, their type, sort, and attractions and activities they offer.

The data in the Tables 1 and 2 indicate that the majority of beaches in the Istrian County, that are flying the Blue Flag, in a majority represent a combination of natural and arranged beaches, followed by beaches which are entirely natural. The authors have registered only two beaches categorized as entirely arranged. A significant majority of them offers a high number of various facilities for children and adults, which should be able to ensure satisfaction for everyone's taste and preferences. But is that so in this particular case? In order to determine the state of bathing tourist offer in the Istrian County and the tourist's attitudes respectively, the authors will present the results of the empirical research carried out.

\section{Attitudes Towards Beach Tourist Offer of the Istrian County}

The authors will present the results of an empirical research, which covers determining the attitudes of the key stakeholders through inquiring tourist's satisfaction with the beach offer. A comparative analysis of the author's research has been carried out with the secondary data gained from the results of the research entitled "Beaches Product of a Tourist Destination" carried on by the Institute of Agriculture and Tourism in Poreč, in 2014, and published in 2016.

The research was carried from $1^{\text {st }}$ to $15^{\text {th }}$ May 2018 on the sample of 173 correctly filled in questionnaires.

By monitoring the socio-demographic characteristics of the respondents, it is visible that $66 \%$ of the question-

\footnotetext{
1 For more information please see https://www.adriagate.com/ Croatia-en/Blue-flag-beaches-Croatia and http://www.blueflag.global/ beaches2/
}

naire was filled by women, and $34 \%$ by men. According to the results of the secondary data of the research from 2014 (2016, pp. 56-61), in terms of gender, the majority of respondents were female (57.0\%), while $43.0 \%$ were male respondents.

By analysing the age structure of the respondents, in the majority prevail respondents in the age group from 25 to $34(41.4 \%)$, followed by $18-24$ (23.6\%), 35-49 (18.7\%), and 50-64 (10.3\%), and in the 65+ group there were only $6 \%$ of the respondents, while according to the 2014 results $33.8 \%$ of them belonged to the age group 35-49, followed by the age group 50-64 (27.4\%), 25-34 (19.2\%), $18-24(12.6 \%)$, while only $6.9 \%$ belonged to the age group $65+$.

All the research participants in the 2018 plan to spend their holiday at a destination, and in comparison with the 2014 results, $72.8 \%$ of the respondents have pleaded that they will spend a holiday at a destination.

In terms of the chosen accommodation during their stay, the majority chose Private accommodation (83\%) and only $17 \%$ a hotel. In 2014, research participants chose for their holiday private accommodation in the majority (29.9\%), a camp (29.0\%), followed by hotel accommodation $(23.5 \%)$.

Table 3 Accommodation during the Stay at a Destination (\%)

\begin{tabular}{|l|c|c|}
\hline \multicolumn{1}{|c|}{ Accommodation } & $\mathbf{2 0 1 4}$ & $\mathbf{2 0 1 8}$ \\
\hline Private accommodation & 29.9 & 83.0 \\
\hline Camp & 29.0 & 0.0 \\
\hline Hotel & 23.5 & 17.0 \\
\hline
\end{tabular}

Source: Author's research; Institute for Agriculture and Tourism (2016, p. 56)

Analysing their way of reaching the beach, in both researches, the respondents stated that they preferred walking (54.8\% in 2014 and $62.9 \%$ in 2018.), by a car $(31.1 \%$ in 2014 and $34.3 \%$ in 2018), while a small amount preferred to use a bicycle, motorcycle and a boat $(14.1 \%$ in 2014 and $2.9 \%$ in 2018). 
Table 4 Reaching the Beach (\%)

\begin{tabular}{|l|c|c|}
\hline \multicolumn{1}{|c|}{ Way of arrival } & $\mathbf{2 0 1 4}$ & $\mathbf{2 0 1 8}$ \\
\hline Walking & 54.8 & 62.9 \\
\hline By car & 31.1 & 34.3 \\
\hline $\begin{array}{l}\text { By bicycle, motorcycle and } \\
\text { boat }\end{array}$ & 14.1 & 2.9 \\
\hline
\end{tabular}

Source: Author's research; Institute for Agriculture and Tourism (2016, p. 58)

In terms of duration of their stay on the beach, the majority preferred to stay longer, respectively, $41 \%$ of the respondents stated, in 2014, that they preferred to spend 3-5 hours on the beach, while, in 2018, that percentage achieved a growth of $18 \% .23 \%$ of the respondents stated in 2014 that they preferred to stay longer than 5 hours, while, in 2018, an increase of $12 \%$ was registered. There was a significant decrease of the results for staying less than 3 hours in 2018 in relation to 2014 (-30\%). These indicators presented the average length of the tourists'stay on beaches, and the time during which they could use potential beach facilities, but also the possibility that, by using interesting beach activities they eventually prolong their stay on the beach.

Table 5 Duration of the Stay on the Beach (\%)

\begin{tabular}{|l|c|c|}
\hline \multicolumn{1}{|c|}{ Duration } & $\mathbf{2 0 1 4}$ & $\mathbf{2 0 1 8}$ \\
\hline 3-5 hours & 41 & 59 \\
\hline Longer than 5 hours & 23 & 35 \\
\hline Less than 3 hours & 36 & 6 \\
\hline
\end{tabular}

Source: Author's research; Institute for Agriculture and Tourism (2016, p. 59)

The data in the following table indicated that, according to the age structure from 2014, the majority of respondents (42\%) most frequently spent their time on the beach with their family, and partners (40\%), while in 2018, according to the age structure, prevailed tourists of a younger age group, which is understandable, considering that they spent the time with their friends on the beach (46\%).

Table 6 Company on the Beach (\%)

\begin{tabular}{|l|c|c|}
\hline \multicolumn{1}{|c|}{ Company } & $\mathbf{2 0 1 4}$ & $\mathbf{2 0 1 8}$ \\
\hline Family & 42 & 23 \\
\hline Partner & 40 & 31 \\
\hline Friends & 15 & 46 \\
\hline Alone & 3 & 0 \\
\hline
\end{tabular}

Source: Author's research; Institute for Agriculture and Tourism (2016, p. 60)
When gathering information on the beach and its facilities, the tourists marked that the previous positive experience had a significant impact, followed by a kind word and information provided in a hotel/camp or a private accommodation. Other sources were marked with a significantly smaller share.

Table 7 Reason for Choosing a Beach (\%)

\begin{tabular}{|l|c|c|}
\cline { 2 - 3 } \multicolumn{1}{l|}{} & $\mathbf{2 0 1 4}$ & $\mathbf{2 0 1 8}$ \\
\hline Sea cleanliness & 51.9 & 91.4 \\
\hline Vicinity of accommodation & 49.3 & 76.5 \\
\hline Beauty of the landscape & 42.6 & 82.4 \\
\hline Beach access & 39.2 & 73.5 \\
\hline Cleanliness of the beach & 37.9 & 76.5 \\
\hline Availability of children facilities & 11.0 & 14.7 \\
\hline $\begin{array}{l}\text { Ability of using props (sunshades, } \\
\text { loungers) }\end{array}$ & 10.9 & 47.1 \\
\hline Ensured parking lot & 9.7 & 55.9 \\
\hline Availability of sports facilities & 8.7 & 23.5 \\
\hline Availability of entertainment facilities & 6.8 & 38.2 \\
\hline Gastronomic offer & 6.4 & 64.7 \\
\hline Ability of brining dogs & 4.7 & 44.1 \\
\hline Ability of boat access & 2.6 & 23.5 \\
\hline $\begin{array}{l}\text { Ability of access for disabled persons in } \\
\text { wheelchairs, etc. }\end{array}$ & 0.7 & 14.7 \\
\hline
\end{tabular}

Source: Author's research; Institute for Agriculture and Tourism (2016, p. 64)

When analysing the reasons why the respondents chose particular beaches, the authors have obtained some very interesting results. When choosing a beach, in 2014, the respondents gave advantage to the sea cleanliness (51.9\%), followed by the vicinity of the accommodation $(49.3 \%)$, beauty of the landscape $(82.4 \%)$, beach access $(39.2 \%)$ and beach cleanliness $(37.9 \%)$. A smaller share marked the importance of children's facilities (11.0\%), the use of beach props (sunshades and loungers) (10.9\%), parking spaces $(9.7 \%)$, sports facilities $(8.7 \%)$, entertainment facilities (6.8\%). The lowest importance was given to the ability of access for disabled persons in wheelchairs, etc. $(0.7 \%)$. In 2018 , the results were a bit different. It is interesting that, besides sea cleanliness (91.4\%) and beauty of the landscape (76.5\%), the respondents emphasized the rich gastronomic offer (64.7\%), sufficient number of parking spaces (55.9\%), but also the ability of brining dogs to the beach (44.1\%).

These results showed how much habits of potential tourists change, and the significance of individual facilities on the beach, so that beaches are no longer the place of passive rest. The variety of beach facilities would significantly influence the prolonged tourists' stay on beaches. 
Table 8 Use of Facilities while Staying on a Beach (\%)

\begin{tabular}{|l|c|c|}
\hline \multicolumn{1}{|c|}{ Facilities } & $\mathbf{2 0 1 4}$ & $\mathbf{2 0 1 8}$ \\
\hline Only owned props & 67.1 & 52.9 \\
\hline $\begin{array}{l}\text { Props available at a beach (sunshades, } \\
\text { loungers) }\end{array}$ & 24.1 & 61.8 \\
\hline Restaurant facilities & 17.6 & 76.5 \\
\hline $\begin{array}{l}\text { Other sport's facilities (volleyball, } \\
\text { mini-golf, etc). }\end{array}$ & 10.0 & 38.2 \\
\hline Children's facilities & 9.1 & 11.8 \\
\hline Music and dancing & 5.8 & 67.6 \\
\hline Scuba-diving facilities & 3.4 & 29.4 \\
\hline Massages on the beach & 3.1 & 38.2 \\
\hline $\begin{array}{l}\text { Adrenaline facilities (ski lift, bungee } \\
\text { jumping, etc) }\end{array}$ & 2.7 & 44.1 \\
\hline Surfer facilities & 0.9 & 29.4 \\
\hline
\end{tabular}

Source: Author's research; Institute for Agriculture and Tourism (2016, p. 66)

The data obtained in the previous table have shown that respondents in 2014 preferred the use of their own props only $(67.1 \%)$, followed by props available at the beach $(24.1 \%)$, restaurant facilities $(17.6 \%)$, other sport's facilities $(10.0 \%)$, children's facilities $(9.1 \%)$. The lowest interest was shown in surfing facilities (0.9\%). However, a change was registered in the tourists' habits in 2018, respectively, when a greater significance was given to the restaurant facilities (76.5\%), music and dancing (67.6\%), available props at a beach (sunshades, loungers) (61.8\%), proper props (52.9\%), and to the adrenaline facilities (ski lift, bungee jumping, etc.) (44.1\%).

The Table 9 presents the grade of the respondent's satisfaction with the individual beach characteristics.

As far as the level of satisfaction with the beaches, the respondents emphasized that, in the majority of cases, the preserved natural resources are important for them, respectively, beauty of the landscape (4.4), sea cleanliness (4.3), beach cleanliness (4.2), vicinity of the accommodation (4.1), beach access (4.0) and bathing space and comfort (3.8). However, what is worrying is the lower grade of some elements which can have a significant reflection on possible future decision-making when choosing a holiday destination, such as parking facilities (3.6), comfort on the beach (3.8) and the relation between the quality and price (3.7) of the offer. They were graded with a lower grade, followed by the ability of using props (3.6), availability of sports facilities (3.4), bringing dogs to the beach (3.3), quality of beach facilities (3.6) and boat access (3.4). The lowest grade was given for the ability of access for disabled persons, wheelchairs, etc. (2.7).

When asked whether, in their opinion, beaches should be themed, most of the respondents replied negatively (more than 66\%). However, when asked if they would have to choose a certain beach theme, the replies proved to have the biggest deviations considering the two periods of research. In 2014, the majority of the respondents chose the theme traditional beach for families with children $(30.8 \%)$, followed by beaches with a romantic theme (16.9\%), beaches with sport facilities $(16.0 \%)$, party beaches $(14.3 \%)$, eco beaches $(12.4 \%)$, etc. A lower interest was

Table 9 Satisfaction with the Beach (grade 1-5)

\begin{tabular}{|c|c|c|c|}
\hline Attributes & 2014 & 2018 & Average \\
\hline Beauty of the landscape & 4.4 & 4.4 & 4.4 \\
\hline Sea cleanliness & 4.3 & 4.3 & 4.3 \\
\hline Vicinity of accommodation & 4.2 & 4.0 & 4.1 \\
\hline Beach access & 4.1 & 4.0 & 4.0 \\
\hline Comfort on a beach & 3.8 & 3.9 & 3.8 \\
\hline Relation of quality and price of the offer & 3.8 & 3.6 & 3.7 \\
\hline Ability of using props & 3.6 & 3.7 & 3.6 \\
\hline Availability of sports facilities & 3.5 & 3.3 & 3.4 \\
\hline Availability of entertainment facilities & 3.4 & 3.7 & 3.5 \\
\hline Availability of facilities suitable for children & 3.4 & 3.6 & 3.5 \\
\hline Gastronomic offer & 3.4 & 4.2 & 3.8 \\
\hline Ability of access for disabled persons, wheelchairs, etc. & 3.0 & 2.5 & 2.7 \\
\hline
\end{tabular}

Source: Author's research; Institute for Agriculture and Tourism (2016, p. 72) 
Table 10 Tendency of the Respondents towards Beach Themes (\%)

\begin{tabular}{|l|c|c|}
\hline \multicolumn{1}{|c|}{ Theme } & $\mathbf{2 0 1 4}$ & $\mathbf{2 0 1 8}$ \\
\hline Beach for families with children & 30.8 & 68.6 \\
\hline Romantic beach & 16.9 & 37.1 \\
\hline $\begin{array}{l}\text { Beach with sports and } \\
\text { recreational facilities }\end{array}$ & 16.0 & 51.4 \\
\hline Party beach & 14.3 & 77.1 \\
\hline Eco Beach & 12.4 & 17.1 \\
\hline Nudist Beach & 11.3 & 11.4 \\
\hline $\begin{array}{l}\text { Beach with entertainment } \\
\text { facilities for young people }\end{array}$ & 10.9 & 48.6 \\
\hline Resort (hotel) beach & 6.5 & 40.0 \\
\hline Dog beach & 6.1 & 31.4 \\
\hline Beach with health advantages & 6.0 & 14.3 \\
\hline Adrenaline beach & 5.9 & 25.7 \\
\hline Diving beach & 5.3 & 17.1 \\
\hline Urban beach & 4.5 & 22.9 \\
\hline Beach of culture & 4.1 & 8.6 \\
\hline Beach for surfers & 3.5 & 22.9 \\
\hline Beach for same-sex couples & 1.6 & 11.4 \\
\hline
\end{tabular}

Source: Author's research; Institute for Agriculture and Tourism (2016, p. 76)

shown for themes such as adrenaline beach (5.9\%), diving $(5.3 \%)$, etc. The lowest grade was given to the beaches for same-sex couples (1.6\%). The results of the research carried on in 2018 have registered changes. The respondents singled out the themes party beach $(77.1 \%)$, followed by beach for families with children $(68.6 \%)$, beach with sports and recreational facilities (51.4\%), while the least interest was shown for themes such as beach of culture $(8.6 \%)$, beach for same-sex couples and nudist beach $(11.4 \%)$.

\section{The Results of the Empirical Research}

Bearing in mind all the previously mentioned facts, the authors have determined the following symptomatic results:

- By monitoring socio-demographic characteristics of the respondents, it can be concluded that in the first monitored period the majority of respondents belonged to the generation group 35-49 of age (33.8\%), while, in 2018, the respondents were mostly younger people belonging to the age group 25-34 (41.4\%), and age group 18-24 (23.6\%). According to their age structure, deviations are present in the beach facilities to which they give greater significance. - In both periods of the research, the majority of the respondents have stated that they will use private accommodation during their stay in the destination.

- They arrive at the beach mostly on foot, then in a smaller ratio they use a car as a means of transport. The previously stated facts have indicated that it would be advisable to have a suitable number of parking places in the vicinity of the beach.

- In both monitored time periods, visitors most frequently stay on a beach from 3 to 5 hours $(41 \%$ in 2014 , and $59 \%$ in 2018). This has indicated the possibility of a prolonged stay on the beach by offering additional facilities and spaces.

- The results indicated that, in 2014, the participants primarily went to the beach in the company of their families (42\%), while, considering that in 2018 the questionnaire was filled in most frequently by a younger population, the respondents stay on the beach in the company of their friends (46\%) and with their partner (31\%).

- The respondents have also stated their priorities when choosing a specific beach. In both the monitored periods, the most important criteria have been sea cleanliness (51.9\% in 2014 , which significantly grew up to $91.4 \%$ in

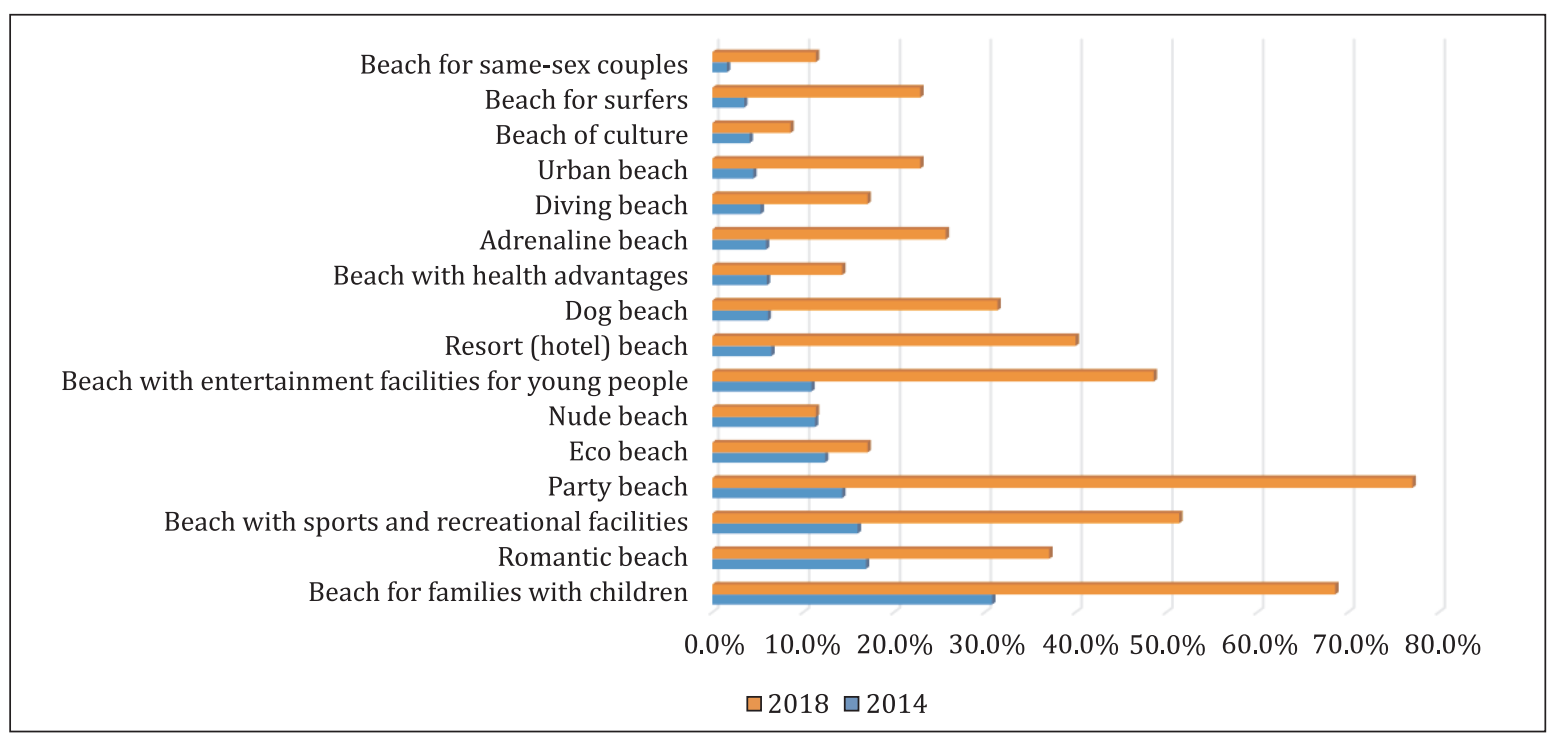

Chart 1 Tendency of the Respondents towards Beach Themes (\%) 
2018). Furthermore, in 2014, they stated the importance of the vicinity of their accommodation, while in 2018 the emphasis was given to the beauty of the landscape and the possibility of additional services on the beaches. A symptomatic datum is that they have paid a great attention to the gastronomic offer $(64.7 \%)$ which was not the case in the previous period of research (6.4\%). During their stay on the beach, in the first monitored period, they were mostly interested in the facilities such as renting loungers and sunshades, while in the second period the advantage has been given to the gastronomy and entertainment facilities (music and dancing). That what has been previously mentioned, can be the reflection of the various age groups that participated in the research.

- When analysing the satisfaction of the participants with individual elements of the beach offer and additional facilities, in both periods the respondents marked beauty of the landscape (average 4.4), and sea cleanliness (average 4.3). The lowest grade was given to the facilities for disabled persons (average 2.7) and facilities on beaches for dogs (average 3.3).

- The tendency of the respondents towards certain beach themes has also been analysed. Beaches for families with children $(30.8 \%)$ and romantic beaches $(16.9 \%)$ were the most recognized ones in 2014, while, in 2018, the greatest attention has been given to party beaches (77.1\%) and beaches with sports and recreational facilities (51.4\%).

In the globalized world, beaches have been recognized as a factor in achieving competitiveness of a tourist product, considering that they represent the main centre of tourism; they have become the icons of contemporary tourism, and they have been considered as the main factors on the tourist market. Bearing this in mind, beaches are becoming significant spaces for social recreation and holiday. They are more and more considered as a highly valuable, not just socio-economic but also ecologic and national resource, which demands effective managing.

\section{Conclusion}

In this paper the authors have carried on the analysis of the existing state of sea beaches in the Istrian County, thus emphasizing, in particular, sea beaches as a resource basis considering the significance of beaches, length of the coastline, beach division, and beach facilities. Furthermore, legal basis has been analysed basically, respectively, the limitations and recommendations for the improvement of the beach managing system. According to the vision of the destination, and with a goal of an optimal distribution of bathers (tourists and domicile population), and with the purpose of providing optimal answers to the tourist preferences, the results of the primary research of the visitor's satisfaction with the beach facilities have been presented in this paper. As an answer to the changing trends in the habits of the potential beach visitors, a comparative analysis of the results of the secondary research carried on in 2014 was presented, as well as the research of the authors carried on in 2018 on the sample of 173 respondents. In other words, within the frame of the existing beach theming, according to the National Program of Sea Beach Managing, it is necessary to determine the adequate facilities and services for beach spaces which, according to the preferences of the visitors, represent the attraction resource of the tourist product of Sun, Sand and Sea. Today, various topics are known which in fact suit the target groups on the market: beaches with sports and recreational facilities, urban beaches, beaches with entertainment facilities for young people, romantic beaches, beaches for surfers, diving beaches, adrenalin beaches, nudist beaches, beaches for families with children, party beaches, beaches with health benefits, beaches of culture, eco beaches, resort beaches, beaches for pets, mixed beaches with various zones, and similar ones. But preferences of visitors have changed significantly in the monitored four year interval (how long has passed between two researches carried on). In the monitored periods, the respondents have given the greatest significance to the natural beauties. The conclusion has imposed that the beach visitors in the first period gave an advantage to the beaches the topics being related to facilities for families with children while in the second monitored period a much greater emphasis has been given to beaches with entertainment facilities and party beaches as well.

\section{References}

[1] Adriagate Travel Agency:: Blue Flag Beaches Croatia, https://www.adriagate.com/Croatia-en/Blue-flag-beachesCroatia (13.03.2018)

[2] Blue Flag.: Blue Flag Beaches, http://www.blueflag.global/ beaches2/ (11.03.2018)

[3] Bojanic, D.: A look at a modernised family life cycle and overseas travel, Journal of Travel and Tourism Marketing, Vol. 1, No. 1, pp. 61-80, 1992.

[4] Duman, T. and Kozak, M.: The Turkish Tourism Product: Differentiation and Competitiveness, Anatolia: An International Journal of Tourism and Hospitality Research, Vol. 21, No. 1, pp. 89-106, 2010.

[5] Dwyer, L. and Kim, C.: Destination Competitiveness: Determinants and Indicators, Current Issues in Tourism, Vol. 6, No. 5, pp. 369-414, 2003.

[6] Garcia Sanchez, A. and Siles Lopez, D.: Tourism destination competitiveness: the Spanish Mediterranean case, Tourism Economics, Vol. 21, No. 6, pp. 1235-1254, 2015.

[7] Goffi, G.: A Model of Tourism Destination Competitiveness: The case of the Italian Destinations of Excellence, Anuario Turismo y Sociedad, Vol. 14, pp. 121-147, 2013.

[8] Gračan, D., Zadel, Z. and Vlahušić, Ž.: Beaches destination management - case study Penninsula Pelješac, Scientific Journal of Maritime Research, Vol. 30, No. 1, pp. 75-81, 2016.

[9] Institute for Agriculture and Tourism.: Beaches product of a tourist destination, Institute for Agriculture and Tourism and Managing Department for Tourism, Poreč, 2016.

[10] Kozak, M.: Measuring comparative destination performance: A study in Spain and Turkey, Journal of Travel \& Tourism Marketing, Vol. 13, No. 3, pp. 83-110, 2002. 
[11] Ministry of Construction and Physical Planning of the Republic of Croatia: Physical Planning and Building Act (NN 76/07, 38/09, 55/11, 90/11, 50/12, 55/12), http://www. mgipu.hr/default.aspx?id=7029 (11.03.2018)

[12] Ministry of the Sea, Transport and Infrastructure of the Republic of Croatia.: Regulation on the procedure for granting a concession on a maritime good (NN 23/04, 101/04, 39/06, 63/08, 125/10 and 83/12), http://www.mppi.hr/ default.aspx?ID=853 (11.03.2018)

[13] Ministry of Tourism of the Republic of Croatia, 2014, National Program of managing and setting beaches Action Plan, http://europski-fondovi.eu/sites/default/files/dokumenti/150205_AP_Nacionalni_program_plazze.pdf (11th March 2018) (11.03.2018)

[14] Official Tourist Portal of Istria, http://www.istra.hr (11.03.2018)

[15] Official Tourist Portal of Istria.; Master Plan of Tourism of Istrian County 2015-2025, http://www.istra.hr/.app/ download.php?file=Master_Plan_Turizma_Istarske_Zupanije_2015-2025.pdf (11.03.2018)

[16] Official Website Best of Croatia Company: Borik Beach, https://www.bestofcroatia.eu/hr/plaze-detalji/plaza-borik-107 (11.03.2018)

[17] Official Website Best of Croatia Company.: Gradsko Kupalište Beach, https://www.bestofcroatia.eu/hr/plazedetalji/plaza-gradsko-kupaliste-porec-104 (11.03.2018)

[18] Official Website Best of Croatia Company.: Kanova Beach, https://www.bestofcroatia.eu/en/beaches-details/beachkanova-109 (11.03.2018)

[19] Official Website Best of Croatia Company.: Laguna Stella Maris Beach, https://www.bestofcroatia.eu/en/beachesdetails/beach-laguna-stella-maris-111 (11.03.2018)

[20] Official Website Best of Croatia Company.: Lanterna Beach, https://www.bestofcroatia.eu/en/beaches-details/beachlanterna-220 (11.03.2018)

[21] Official Website Best of Croatia Company.: Lotosi Beach, https://www.bestofcroatia.eu/en/beaches-details/beachlotosi-hotel-plavi-646 (11.03.2018)

[22] Official Website Best of Croatia Company.: Maslinica Beach, https://www.bestofcroatia.eu/en/beaches-details/beachmaslinica-217 (11.03.2018)

[23] Official Website Best of Croatia Company:: St. Andrea Beach, https://www.bestofcroatia.eu/hr/plaze-detalji/plaza-st.andrea-219 (11.03.2018)

[24] Official website of a tourist agency Istriasun.: Katoro Beach, http://www.istriasun.com/istra/katoro-plaza (11.03.2018)

[25] Official website of a tourist agency Istriasun.: Mareda Beach, http://www.istriasun.com/istra/mareda-plaza (11.03.2018)

[26] Official website of a tourist agency Istriasun.: Valeta AC Lanterna Beach, http://www.istriasun.com/istra/valeta-plaza (11.03.2018)

[27] Official website of Adriagate Travel Agency:: Bi-Val Beach, https://www.adriagate.com/Hrvatska-hr/Plaza-Bi-ValFazana-Hrvatska (11.03.2018)

[28] Official website of Adriagate Travel Agency: Brulo Beach, https://www.adriagate.com/Hrvatska-hr/Plaza-Brulo-Porec-Hrvatska (11.03.2018)

[29] Official website of Adriagate Travel Agency.: Plava Laguna Beach, https://www.adriagate.com/Hrvatska-hr/Plaza-Plava-Laguna-Bellevue-Porec-Hrvatska (11.03.2018)
[30] Official Website of Aminess Hotels \& Camps.: Maestral Beach, https://www.aminess.com/hr/aminess-maestralhotel/plaze-i-bazeni (11.03.2018)

[31] Official Website of Aminess Hotels \& Camps.: Sirena Beach, https://www.aminess-campsites.com/en/aminess-sirenacampsite (11.03.2018)

[32] Official Website of Arenaturist Hotels \& Resorts.: Ambrela Beach, https://www.arenaturist.com/en/destination/ pula/beaches\# (11.03.2018)

[33] Official Website of Arenaturist Hotels \& Resorts.: Brioni Beach, https://www.arenaturist.com/en/destination/pula/ beaches\# (11.03.2018)

[34] Official Website of Camping by Valamar: Vala Beach, https://www.camping-adriatic.com/orsera-camp-porec/beach (11.03.2018)

[35] Official website of Istraturist Hotel Resorts \& Campsites.: Coral Beach, https://www.istraturist.com/hr/hoteli/meliacoral/opis (11.03.2018)

[36] Official website of Istraturist Hotel Resorts \& Campsites.: Sipar Beach, https://www.istraturist.com/en/hotels/sipar/ description (11.03.2018)

[37] Official Website of Laguna Poreč Hotels Resorts \& Camping.: Beach of Naturist Center Ulika, https://hr.lagunaporec com/kamp-naturist-centar-ulika-porec/sadrzaji?bs= (11.03.2018)

[38] Official Website of Laguna Poreč Hotels Resorts \& Camping.: Laguna Parentium Beach, https://lagunaporec.com/hotellaguna-parentium-porec (11.03.2018)

[39] Official Website of Laguna Poreč Hotels Resorts \& Camping.: Laguna Galijot Beach, https://lagunaporec.com/villa-laguna-galijot-porec (11.03.2018)

[40] Official Website of Laguna Poreč Hotels Resorts \& Camping.: Špadići-Materada Beach, https://lagunaporec.com/hotellaguna-materada-porec/facilities?bs= (11.03.2018)

[41] Official Website of Maistra Camping Rovinj Vrsar: Polari Beach, https://www.campingrovinjvrsar.com/campsites/ polari_rovinj/beaches (11.03.2018)

[42] Official Website of Maistra Camping Rovinj Vrsar: Porto Sole, https://www.campingrovinjvrsar.com/campsites/ porto_sole_vrsar/beaches (11.03.2018)

[43] Official Website of Maistra Camping Rovinj Vrsar.: Valkanela Beach, https://www.campingrovinjvrsar.com/hr/kampovi/ valkanela_vrsar (11.03.2018)

[44] Official Website of Maistra Camping Rovinj Vrsar:: Veštar Beach, https://www.campingrovinjvrsar.com/campsites/ vestar_rovinj/beaches (11.03.2018)

[45] Official Website of Maistra Hotels \& Resorts.: Amarin Beach, https://www.maistra.com/amarin-rovinj/beachespools\#top (11.03.2018)

[46] Official Website of Maistra Hotels \& Resorts.: Belvedere Beach, https://www.maistra.com/belvedere-vrsar/beaches-pools\#top (11.03.2018)

[47] Official Website of Maistra Hotels \& Resorts.: Koversada Beach, https://www.maistra.com/koversada-apartmentsvrsar/beaches\#top (11.03.2018)

[48] Official Website of Maistra Hotels \& Resorts.: Rubin Beach, https://www.maistra.com/hr/rubin-rovinj/plazebazeni\#top (11.03.2018)

[49] Official Website of Maistra Hotels \& Resorts.: Sveti Andrej Beach, https://www.maistra.com/all-suite-island-hotelistra-rovinj/beaches-pools\#top (11.03.2018) 
[50] Official Website of the Tourist Board of Poreč.: Crnika Lantern Beach, https://www.myporec.com/hr/sto-raditi/plaze/8 (11.03.2018)

[51] Official Website of the Tourist Board of Poreč.: Donji Špadići Beach, https://www.myporec.com/en/what-to-do/beaches/12 (11.03.2018)

[52] Official Website of the Tourist Board of Poreč.: Galeb Beach, https://www.myporec.com/en/what-to-do/beaches/9 (11.03.2018)

[53] Official Website of the Tourist Board of Poreč.: Lagoon Bellvue Beach, https://www.myporec.com/hr/sto-raditi/ plaze/17 (11.03.2018)

[54] Official Website of the Tourist Board of Poreč.: Laguna Materada Beach, https://www.myporec.com/hr/sto-raditi/ plaze/11 (11.03.2018)

[55] Official Website of the Tourist Board of Poreč.: Riviera Beach, https://www.myporec.com/hr/sto-raditi/plaze/346 (11.03.2018)

[56] Official Website of the Tourist Board of Poreč.: Zelena Laguna Beach, https://www.myporec.com/hr/sto-raditi/plaze/22 (11.03.2018)

[57] Official Website of tourist agency Gradtur d.o.o. and hrvaska.net.: Delfin Beach, https://www.hrvaska.net/en/hotels/ porec/hotel-delfin-porec.htm (11.03.2018)

[58] Official website of Travelana d.o.o. Travel Agency.: Molindrio hotel beach, http://www.travelana.hr/hotel-LAGUNAMOLINDRIO.aspx?ignorePriceAndAvailability=1\&person s=2\#;basicInfoTab, (11.03.2018)

[59] Official website of Uniline Travel Company.: Bijela Uvala Beach, http://www.uniline.hr/hrvatska/kamp/bijela-uvala-mh-porec.php (11.03.2018)

[60] Official Website of Valamar Hotels \& Resorts.: Girandella Beach, https://www.valamar.com/hr/hoteli-rabac/valamargirandella-resort/plaza-bazen-wellness\#beach (11.03.2018)

[61] Porter, M.E.: Competitive Strategy: Techniques for Analyzing Industry and Competitors, Free Press, New York, 1980.
[62] Pula Travel Guide PulaCroatia.: Barbariga Beach, http://www.pulacroatia.net/item/barbariga-beach/ (11.03.2018)

[63] Pula Travel Guide PulaCroatia.: Histria Beach, http://www. pulacroatia.net/item/histria-beach-pula/ (11.03.2018)

[64] Ritchie, J. R. B. and Crouch, G. I.: The competitive destination, a sustainable perspective, Tourism Management, Vol. 21, No. 1, pp. 1-7, 2000.

[65] Semeoshenkova, V.S. and Williams, A.T.: Beach quality assessment and management in the Sotavento (Eastern) Algarve, Portugal, Journal of Coastal Research, Vol. 64 (Special issue), pp. 1282-1286, 2011.

[66] Statistical Bureau of the Republic of Croatia.: www.dzs.hr (13.03.2018)

[67] Tourist Board of Funtana.: Auto-Camp Beach Istria, http:// funtana.com/kamp/istra-naturist-camp/ (11.03.2018)

[68] Tourist Board of the city of Vodnjan.: Peroj Beach, http:// vodnjandignano.com/index.php?option=com_content $\&$ view $=$ article \&id $=213 \&$ Itemid $=514 \&$ lang=en Peroj Beach (11.03.2018)

[69] Vaz, B., Williams, A.T., Silva, C., and Phillips, M.: The importance of user's perceptions for beach management, Journal of Coastal Research, Vol. 54 (Special issue), pp. 1164-1168, 2009.

[70] Williams, A. and Micaleff, A.: Beach Management: Principles \& Practice with invited case study contributions, Earthscan, UK and USA, 2009.

[71] Zadel, Z. and Cerović, M.: Quantitative and qualitative trends on the Croatian tourist market in Croatia, 4th scientific-professional congress in memoriam Vjekoslav Šmid: "Actualities of civil law, law in tourism, civil and maritime law, and Administrative Law", June 6-8, 2013, Rab, Croatia, pp. 399-411.

[72] Zadel, Z.: Beaches in the function of primary resource of the beach tourism product, Journal of Maritime and Transportation Sciences, Vol. 49-50, pp. 117-130, 2016. 